\title{
Educating future scientists towards post-patrimonial governance
}

\author{
Dorothy V. Smith ${ }^{1}$
}

Received: 23 July 2019 / Accepted: 9 August 2020 / Published online: 25 November 2020

(c) Springer Nature B.V. 2020

\begin{abstract}
In this article, I use the idea of post-patrimonial governance to consider the science education of future scientists. I argue, with Anna Yeatman, that the politics of our time is structured by a contest between two kinds of post-patrimonial contractualism. Data are reported from a study of contemporary Australian scientists to show that some scientists are successfully conducting professional relationships with their publics that are consistent with what Yeatman has called the new contractualism. These approaches contrast with the neopatrimonial contractualism that typifies neoliberal governance and which is prevalent in many societies today. Science educators face a choice to provide accounts of science that acknowledge the work of these scientists and that prepare both future scientists and their future publics for professional relationships of reciprocal respect. I suggest approaches for school science education that are consistent with such a choice.
\end{abstract}

Keywords Neoliberalism · Post-patrimonial governance $\cdot$ Contractualism · Scientists · STEM education

The majority of students in school classrooms today will not work in science; policy visions for school education should take seriously the present and future needs of this majority (Malcolm 2003). In Australia, where this study is set, these apparently simple recognitions have driven many science educators since at least the Science for All movement of the late 20th century (Fensham 1985) and they are the motivations for this article. However, deciding precisely what might count as an appropriate school science education for future non-scientists has not been easy, in part because school science education has also been seen as having a clear remit for the education of future science specialists and the needs of these future scientists are generally seen as different from those of non-scientists. Generally, future scientists are seen as needing to learn more technical specialist knowledge and also as needing to be inducted into a particular view of science. To be clear, it is

Lead Editor: Ajay Sharma.

Dorothy V. Smith

dorothy.smith@une.edu.au; dorothy.smith@latrobe.edu.au

1 Department of STEM Education, School of Education, University of New England, Armidale 2351, Australia 
not my view that future scientists and non-scientists need school education that is dramatically different, one from the other. My point, rather, is that this has been a belief that has prevailed in science education policy and curriculum development for years.

In this article, I propose to consider a science education that meets the present and future needs of all students by considering the professional needs of future scientists. This is a counterintuitive step and I take it because, as I have argued elsewhere (Smith 2011), the needs of future scientists and the attendant disciplinary well-being of science continue to be the de-facto driver of science education policy and its expression in school science curricula. Hence, it is worth surfacing and critiquing this ongoing preoccupation on the part of policy makers and curriculum developers. School science today does not meet the needs of intending scientists because it presents an outmoded account of the relationships between scientists and non-scientists. Thus, school science prepares neither future scientists nor non-scientists for the ways in which contemporary scientists relate to their publics and their communities.

Given the forms of neoliberal governance that drive contemporary society, this is a dangerous omission. Jasanoff's (2013) insight that science and society co-produce each other applies to the mainstream of science; hence, what counts as the disciplinary well-being of science changes as society's vision for the purposes and scope of science changes. The international trend to STEM Education has positioned science and technology education as a driver of specific forms of economic well-being for states and nations (see, for example, Weinstein 2016 for a discussion of STEM in the USA and Carter 2017 for Australia). In this positioning, the disciplinary well-being of science is associated with a ready supply of willing trained workers and the dilemma of educating future scientists and future non-scientists in the same classroom is solving by treating all students as potential STEM entrepreneurs or STEM workers. In Australia this is not a likely outcome even for university science graduates (see, for example, Palmer, Campbell, Johnson and West 2018), but the possibility of this outcome is a key driver of education policy and STEM rhetoric. It is important for both science and society that this is not the only account of science and the work of scientists that is presented to students in schools.

My intention in seeking to make this argument in this journal is to add my voice to those who have in these pages critiqued and challenged neoliberalism's narrowing of science, technology and environmental education policy: here, I have in mind the 2017 Special Issue Biopolitics and Science Education (Carter, Weinstein and Bencze 2017) and Annette Gough's analysis of the parallel trajectories of environmental education and science education (Gough 2015). The theoretical and political landscape on which this argument is constructed includes Darren Hoeg and Larry Bencze's (2017) account of education policy as a mechanism able to produce political outcomes by governing into existence subjectivities, knowledges and practices in citizens. Increasingly, neoliberal networks govern into existence the types of citizens needed to perpetuate neoliberal governance: the democratic political citizen is replaced by the individualist economic anti-citizen (Marginson 1997). Education policy is a key site of activity for these networks, and through them new narratives are articulated and validated about what counts as a "good" education (Ball 2008): with this comes a view of what counts as being an individual, what counts as society, and what counts as being a citizen. Consequently, science education should offer accounts of science that equip scientists and other citizens to work with each other in a wide variety of ways, including but not restricted to, those of the market.

This analysis is conducted using a theory of the relationships between individuals and community developed by Anna Yeatman (see, for example, Yeatman 2000). Yeatman (2002) argues that any examination of individuality must take seriously the rich tradition 
of liberal thought because it provides an insight into a particular, historically important account of individuality. A classical liberal account of the individual underpinned Friedrich Hayek's influential formulation of neoliberalism (see, for example, Hayek 1978), and my argument below is strongly shaped by these sources, and by the work of David Harvey (2007), Jeremy Gilbert (2013) and Lynn Carter (2018). Here, the term neoliberalism refers to a broad set of discursive practices, particularly as they relate to policy and public-sector governance, and these particularly as they relate to education in general and specifically to science education.

\section{The individual, contract and forms of governance}

Below, broad meanings of the individual, contract, contractualism and post-patrimonial governance are considered before a move to apply them to the particular instance of the relationships between scientists and their communities. Throughout this article, I am thinking about situations in which a scientist with specialist knowledge or skill provides support to those who do not share that knowledge or skills. I am particularly concerned with what these ideas and choices mean for the work of scientists and other STEM professionals in neoliberal marketised societies such as Australia, and consequently with the ways in which school education might prepare future citizens for this work.

\section{The liberal individual and patrimonial governance}

Historically, liberalism centres on a particular conception of an individual as a person who "possesses mature contractual capacity and who exercises this capacity on behalf of his and (as it now is) her freedom to be both self-governing and self-reliant" (Yeatman 2002, p. 70). This individual is free to do as he or she wills, and since individuals can only function in society with interactions with and assistance from others, liberalism admits the existence of these interactions. However, it structures this recognition in accordance with the fundamental conception of a human subject as "an individualized unit of private property" (Yeatman 2002, p. 70). Thus, the dependence of an individual on others is structured according to two possible views. The first of these is as an exchange relationship in which the nature of the exchange confirms each in his or her standing as private individuals free to do as they will: the ability to form a contract is one expression of this freedom and equality of standing. The second type of relationship is one of command over others, in which these others are subject to the will of the self-governing individual.

Where the first type of relationship of the liberal subject-the reciprocity of an exchange relationship - offers recognition to the individuality of those party to it, the second type of relationship of the liberal subject is predicated on a profound inequality. The individuality of the patrimonial head of the unit concerned, whether it is a family or firm, swallows up that of his dependants. They are to have no individuality of their own for the duration of their dependence on his government of them. (Yeatman 2002, p. 70).

Patrimonial governance is modelled "along the lines of a patrimonial household, owing care and protection to those who are viewed as both the subjects and dependents of this household" (Yeatman 2000, p.170). It confers this protection through a relationship of command and in exchange for subsuming and thereby concealing the individuality of the 
recipient. Patrimonialism characterised the foundations of modern democratic governance in three ways: firstly, the capacity to be a citizen was associated with the capacity to be self-governing and this was framed in terms of the capacity to take responsibility for a household; secondly, patrimonial assumptions framed conceptions of economic management; and thirdly, state administration of needs is informed by patrimonial assumptions that equate need with dependency (Yeatman 2000). Thus, colonial states and, in Australia, the post-war welfare state were structured to allow experts-scientists, for example-to assume a right to speak on behalf of the laity: they offered protection in exchange for obedience (Carney, Ramia and Yeatman 2001).

Science education that imagined a patrimonial relationship between experts and the laity would prioritise the education of future scientists, because they would be the only keepers of existing knowledge and producers of new knowledge. It would prioritise the transmission and accurate acquisition of knowledge and skills, and ideally it would include a formal consideration of ethics, both in terms of the ethical conduct of science and also in consideration of ethical relationships with society. Many of the post-war science curriculum projects provide a patrimonial account of the work of scientists (see D. V. Smith 2007 for an analysis of PSSC Physics). In Australia, these projects were and continue to be tremendously influential in shaping the views of teachers and curriculum developers as to what should count as school science (Fensham 2016).

\section{Challenges to liberal patrimonialism}

Liberal patrimonialism faced two key challenges. The first of these came from the assertion of individuality by people who under classical liberalism were not regarded as being self-governing but who now claim that capacity: wives, employees and the colonised. Historically, these groups claimed this right by constituting themselves as self-governing, reasoning mature individuals, and by doing so they sustained modern democratic patrimonialism by making it more inclusive. The right for self-governance was claimed through social movements such as the USA civil rights movement, the second wave of feminism and the women's health movement, participatory democratic student movements, the Vietnam veterans' movement in its activity of seeking rights for US soldiers with disabilities, the wider disability movement and indigenous peoples' movements for self-determination. What was, and continues to be, challenged in these cases is the appropriateness of a command relationship; through these challenges many people now expect to give individualised consent to what is done on their behalf and to be treated as an individual in how others connect and relate to them. In many cases these movements have both initiated and benefitted from a movement of the state to a more publicly accountable and participatory model of administration (Yeatman and Owler 2001). Although the initial challenges came from groups who might constitute themselves as self-governing, a further level of challenge has been "made on behalf of those for whom the metaphors of self-government will always be inappropriate because they lack the capacities to be self-governing" (Yeatman 2000, p.175), for instance, people with relatively severe intellectual and/or psychiatric disability, including older people with dementia.

The second challenge to democratic patrimonial governance questions the idea that one person might owe care and protection to another. Neoliberalism is generally thought to have evolved from classical liberalism (Gilbert 2013), and it shares with classical liberalism the ideal of a free market "based solely on individuals linked by contract and exchange" (Marginson 1997, p. 103). However, at the heart of neoliberal ideology is a view 
that self-interest is the only motive force in human life, that individual interests are mutually exclusive and that competition is the most socially beneficial way for this tendency to self-interest to express itself. The self-interested individual must be governed to act in the interests of the economy lest "commercial producers, workers, service providers, managers and government officials act only in their selfish corporate interests" (Gilbert 2013, p.9). In this way the idea of collectivism is narrowed to have an economic meaning and neoliberalism hijacks the idea of the classical individual who was able to see himself (choice of pronoun is deliberate) as a head of a household, a member of a tribe or clan, or a citizen within society and replaces it with the idea of an individual as "an ambulatory center of selfishness" (Saul 1997, p. 2).

\section{Contractualism}

Contractualism sees social interactions and obligations as being mediated by individual consent and insists upon the rights and freedoms of these individuals. In liberal terms, this means that contract is only available to those who might be constituted as individuals rather than as a dependent. Contractualism has been critiqued as perpetuating a particular form of individualism that is gendered and associated with repugnant paradigms of race and class. For example, Carol Pateman (1988) argues that contract does not secure freedom and equality but rather, for women, ensures the opposite because it is the means by which patriarchy is upheld: thus, the contracting individual is male and ineluctably engaged in a project of control. Similarly, Charles Mills (1997) wrote of a racial contract structured so that the contracting individual is seen to be white. In a different type of critique based on sociopolitical and legal theory Terry Carney and Gaby Ramia (2001) distinguish between contract and citizenship. For them, contract is essentially about the private transactions of individuals in economic exchange but not the public actions of individuals as citizens and to use ideas of contractualism in the context of the public sphere risks eroding the public sphere of citizenship in the interests of a market economy. Critiques of this type argue for rejecting the idea of contract in favour of other ways of thinking about individuals and community.

By contrast, Yeatman (1997) proposed that contractualism might be made to work in a way that acknowledges individual status and does not equate the need for support with deprivation of freedom. She pointed out that the freely contracting adult of classical liberal theory was by no means independent of support and protection, but rather that the support went unacknowledged: for example, sons of private individuals were afforded patrimonial protection as sons until they were able to become individuals in their own right but even after they had ceased to be seen as in need of protection society was structured to award them support and protection. Logically, then, protection or support can be awarded without loss of freedom. From this argument, Yeatman proposed a "new contractualism", or "relational contractualism" (Yeatman and Owler 2001), in which the starting point for a relationship is to acknowledge "the status condition of contractual individuality" (Yeatman 1997, p.52) and then to ask what social support or intervention might be needed in order that the individuality be acknowledged and maintained.

The new contractualism is a form of governance that recognises the work done by the community initially to bring about a capacity for choice, and the continuing work that is done to support agency both in cognitive and physical terms. To paraphrase Yeatman:

[T] he universalisation of contractual responsibility tables clearly for view the fact that some individuals are more contractually capable than others, [and then] the issue 
of social responsibility for bringing about equality of contractual standing comes into view. ... [As a consequence] the right of choice cannot be an effective right except as it is resourced through publicly funded information and advocacy services (Yeatman 1997, p.52).

Under the liberal contractual model, contract governs entry to and exit from relationships. In the new contractualism, conduct within a relationship is seen in a new way: the contractual equality of persons must be respected and supported throughout the term of the relationship. As Yeatman pointed out, "For individuals to conduct their relationships according to contractual norms, their capacities to do so have to be developed, maintained and resourced" (Yeatman 1997, p.52). Incentives must be created for "more powerfully positioned individuals to share their power with the less powerfully positioned individuals $\ldots$ and to abandon patrimonial command and control methods in favour of more co-operative and democratic ones" (Yeatman 1997, p.52).

\section{Forms of post-patrimonial contractualism}

For Yeatman, the politics of our time is structured by a contest between two kinds of postpatrimonial contractualism. Both are post-patrimonial in that they insist on the value of individualised consent. One of these, relational contractualism, seeks to provide support as part of an ongoing relationships of reciprocal respect; the other is a form of neopatrimonial contractualism that maintains patrimonial lines of command relationships. This neopatrimonial contractualism lays out a stringent program of obligation for each individual while it denies the patrimonial duty of care: "[t]he older patrimonial economy where the householder owes protection to his dependents has gone" (Yeatman 2000, p.184).

In its insistence on the value of individuality, neopatrimonial contract is ideally suited to neoliberal governance. Responsibility is individualised, institutions for solving problems are transformed into institutions for creating problems (Beck 1997), or as Zygmunt Bauman (2013) puts it, "you are, on the one hand, made responsible for yourself, but on the other hand are dependent on conditions which completely elude your grasp (and in most cases also your knowledge)" (p. 5). Each individual is forced into a position of deciding for themselves ....

What is still tolerable and what is no longer? They require decisions about whether or not, when, and where to protest even if this only takes the form of an organized, intercultural consumer boycott. These issues raise questions about the authority of the public, cultural definitions, the citizenry, parliaments, politicians, ethics and selforganization (Beck 2000, p. 218).

Neopatrimonial governance replaces the noblesse oblige of patrimonial governance with the caveat emptor of the market. A key consequence of framing independence in a manner derived from patrimonial governance is that it becomes preferentially accessible to those who are culturally comfortable with the rules of a patrimony. Usually, this means those who have formed the elites. Despite all the theorising to the contrary, what we have today in our neopatrimonial neoliberal states is the individualisation of an aristocratic-kinship order and those accustomed to this order are best placed to take advantage of it.

A shift of responsibility from institutions to individuals clearly has consequences for science and science education. It problematises the relationships between scientists and other such professionals with specialist knowledge and skills (Layton, Jenkins, Macgill and Davey 1993, call them experts). It problematises the relationships 
between scientists and the people with whom they interact who do not have that particular knowledge or skill (or, again after Layton et al. 1993, the laity). Experts working within the neoliberal imaginary are likely to see themselves as contributing to economic growth and production and place less emphasis on building community or supporting citizens to participate in science and technology-related decision-making; laity working within this imaginary are likely to try to handle issues for themselves rather than seeking support that might entail consenting to a command relationship, whether it be a patrimonial or neopatrimonial one. This, in turn, raises a number of questions about the capacities that education should attempt to instil in non-scientists: questions about the nature and extent of the scientific knowledge and skills the laity need if they are to operate as neoliberal individuals; questions about the ways in which they should be prepared to interact with atomised and remote decision-making processes; and questions about the extent to which they need to be equipped for political action in the context of their science and technology studies.

However, although neoliberalism has impacted upon the patrimonialism of the postwar welfare state, it also has been forced to operate on the terrain of the post-war welfare state. Thus, contract has been reshaped by its application to government-funded services (Yeatman 2000) and the need to operate on a terrain shaped by citizen activism and challenges to patrimonial practices. Anna Yeatman and Kathryn Owler provide instances of three types of situations in which a service relationship has a foundational role: that of providing intimate personal care, that of a teaching and learning relationship and that of providing services to people who are mentally ill. These are areas where effective delivery of the service depends on intelligent interaction and sophisticated communication to build a relationship between the client and the provider, or as Yeatman and Owler call them, the worker and the consumer.

By intelligent interaction, we mean that the worker uses his or her skills and experience to position both individuals so that they draw upon their respective strengths in the interaction. By sophisticated communication, we mean that the two individuals are able to talk functionally about matters that are difficult, sensitive and emotionally charged for the consumer and, that thereby, the consumer becomes more aware of his or her needs and wants. Where the service relationship assumes this foundational character, there is likely to be a degree of intimacy between staff and consumer and, following on from this, a reciprocity of gift exchange where the nature of the gift concerns an aspect of self (Yeatman \& Owler 2001, p. 35).

If this thinking is extrapolated to other professions, at its simplest it means that future disciplinary specialists - scientists, for example — must understand that their work as specialists entails more than a grasp of specialist knowledge, skills and dispositions. Rather, their work also entails understanding the contexts in which specialist knowledge, skills and dispositions are employed and the meanings that the knowledge might have for those for who use it. They must understand that there are different ways of seeing things. Their knowledge of science must be broad and flexible enough to admit different possibilities and they need a strong understanding that context can influence what counts as a right answer to a problem, and indeed, what counts as a problem. Most importantly, they must have the capacity to engage in relationships of reciprocal respect with people who do not have their knowledge, do not share their skills and do not share their view of what is important. They must have the capacity to support the individualised voice of the other and to talk about matters that are difficult, sensitive and emotionally charged in ways that not only support the other, but also draw out the other's needs and wants that might be supported. 


\section{The study}

The study reported in this article was directly theorised using Yeatman's formulation of the new contractualism. One aim of the study was to investigate whether Australian scientists might be counted amongst those specialists who recognised the need or the possibility of interacting with their communities in intelligent interactions to build relationships of reciprocal respect, and in ways that were consistent with the new contractualism. As we expressed it at the time, our goal was to understand how scientists see the members of the public with whom they interact. Another goal was to articulate a framework for a socially responsible science curriculum that encompasses all citizens, whether they be prospective scientists or not.

This research was carried out at a time when a number of social issues on which science had a bearing were being debated in Australia, and these debates were acrimonious and divisive: the possibility of human-induced climate change was perhaps the most significant of these; others included vaccination, and the need for regulation of water use for farming and agriculture. As we sought participants and arranged for the interviews, we became aware of the significant extent to which the acrimony of these debates impacted on the daily lives and safety of some Australian scientists, and consequently on their ability to do their work. In keeping with the ethics requirements of the author's institution names have been withheld from reporting this research. However, for added protection of participants' anonymity, pseudonyms used in other reports of this study have been entirely withheld in this article.

\section{Participants}

The data reported here were produced in a qualitative study of 36 Australian scientists. The scientists satisfied one or both of two key criteria: their work brought them into contact with one or more sectors of the public, or they taught a first-year subject at a university. All the scientists were research active, and all had done scientific research at some stage in their working lives, although some had moved into other areas of research, mainly in education. Some of the scientists interviewed for this study have a high profile across Australia and internationally, others work more privately within their communities. Of the 36 scientists, only two had worked in science for less than ten years (both had done so for 9 years); 28 scientists had worked in science for 20 years or more; 17 of these 28 had worked in science for 30 years or more and 8 had spent 40 years or more in science, with one reporting 50 years.

Many of the findings of this study have already been reported elsewhere: we have reported the commitment of these scientists to openness in relationships between science and society (Mulhall, Smith, Hart and Gunstone 2017); have considered the account of science given to first-year students at an elite Australian university (D. V. Smith, Mulhall, Gunstone and Hart 2015); have considered the relationships between high-profile Australian scientists and the community (D. V. Smith, Mulhall, Hart and Gunstone 2016); and argued for fresh companion stories for secondary school science (D. V. Smith, Mulhall, Hart and Gunstone 2018). However, none of these reports have drawn directly on the underpinning theorising of the study in the way that it is done in this article. Because the findings involving high-profile scientists have been reported elsewhere the focus of this article will be largely, although not exclusively, on the views of the other scientists. 


\section{Research questions}

The analysis given here asks and answers the following questions:

1. With what range of groups did the scientists interact?

2. Might their interactions be characterised as adopting a post-patrimonial stance congruent with new contractualist governance? Specifically, did they describe their interactions with the public in terms that indicated a command relationship or one that might be described as a desire for reciprocal respect?

3. Where scientists were seeking intelligent interactions with the public, were there aspects of their secondary education that had supported their ability to develop these?

Data production was by a one-on-one interview of between 90 - and 120-min duration. At the start of each interview, the scientist was asked to fill out a sheet to give an indication of their education and the types of work they had done as a scientist. Each was asked to nominate an area of science in which they worked. The interview explored how the scientific work of each scientist involved interaction with community and other groups; the skills required to interact with those different groups, and how they developed those skills; how they saw the relationship between science and society and their own experience of science in school. Diagrams and graphs were used during the interviews as elicitation aids (further details can be found in D. V. Smith and Mulhall 2015). The interview data were interrogated using a process of multiple readings for emergent themes (J. A. Smith and Osborn 2008).

\section{Findings}

\section{Areas of scientific expertise and the groups with whom the scientists interacted}

The scientists interviewed for this project nominated a range of areas as their areas of scientific research, past or present. Some nominated scientific fields or disciplines such as mineralogy, taxonomy, entomology, surface science, astronomy, immunology and behavioural and evolutionary biology. Others described the contexts in which they worked or the broad problems on which they worked: examples include climate change research, forensic science (crime scene research), water efficiency in farming and bushfire research (bushfire is an Australian term for forest fire).

The scientists interacted with a wide range of groups. The largest number of different groups with which a scientist indicated interacting was twelve and the smallest number was four: this smallest number was reported by an academic scientist who did contract research with industry. The groups with whom they interacted included: business, industry and finance groups; community groups and community educators; nongovernmental organisations and special interest groups; citizen scientists; providers of essential services such as firefighting authorities, water, emergency services, health services; farmers, farming systems groups and farm consultants; the general public; government regulatory authorities and resource managers; Australian indigenous communities; land and site managers; non-scientist professionals, such as lawyers, engineers and architects; the media; policy makers, senior policy makers and government officials 
(international, federal, state, local); politicians and political parties; schools/school students/school teachers; scientists who work in different fields or disciplines to the scientist and social scientists.

In addition, the scientists interacted with a range of people within their organisation or allied with it. These included: funding agencies/bodies; non-scientific colleagues who work in same organisation (e.g. marketing, management); non-scientists with expertise relevant to scientist's area of interest; professional organisations involving scientists with similar broad interests; providers of digital technologies or other support for research; research organisations such as universities or Australia's Commonwealth Scientific and Industrial Research Organization; tertiary educators and university officials.

\section{The scientists' reasons for interacting with these groups}

Many contemporary scientists work on complex problems that require input from a variety of scientific and non-scientific sources. For example, for a bushfire researcher understanding the experiences of people who had been through a bushfire forms an important part of his or her job, and some scientists in this study work closely with farmers and needed the information they provided as well as access to their land for data production. As one agriculture researcher told us:

... I'd say most of my research is field-based. ... over the last couple of years I've spent typically ... two days out of five in the field doing experiments mostly, but also some monitoring of farmers' paddocks (Scientist A).

For some scientists direct contact with the sectors of the public to provide information is an integral part of their job. For example, senior forecasters in the Australian Bureau of Meteorology regularly speak on the radio to provide weather forecasts and scientists who work in museums have an educative component in their role. One scientist interviewed for this study is a forensic scientist and his/her job involved interacting with representatives of the legal system as an expert witness and also providing occupational health and safety advice. For some scientists their contact with the public has a discretionary element: the contact may begin as part of their work and then continues into their personal time. This may involve, for example, setting up citizen science initiatives. A bushfire researcher who gave evidence in court and undertook debriefing meetings with communities that had experienced fire explained that:

I'm not given time to do it. [My employers] don't discourage the opportunity, but it's all more or less done on a ... if you see that's beneficial for you, then by all means do it, type of process, and most of it I guess is done in personal time. (pseudonym withheld for anonymity)

Many of these scientists had shaped their careers to allow them to work in these ways. In part this was because it gave them personal satisfaction. For example, a scientist told of how his/her aspirations changed from working in a particular industry to working in a different area that allowed greater community involvement, greater involvement with policy development and an opportunity to influence community behaviour. However, in addition to their career satisfaction there was also a strong sense of duty and commitment to a vision of a good society amongst many of these scientists (D. V. Smith et al. 2018). Arguably, then, working in the ways they did gave them a broader personal satisfaction. 


\section{The ways in which these scientists tried to interact with their publics}

Many scientists in this study felt that they had a responsibility to interact with the public on the public's terms (D. V. Smith et al. 2018). They hoped for interactions that were a two-way exchange between equals and tried to be open to the public, both in terms of being open to new perspectives on their work and also in terms of being open about the scope and limitations of their science.

Most scientists conveyed a sense of familiarity in their interactions with the community and also with how the science they produced applied to the lives of the people with whom they interacted. They spoke of the need to build solid relationships with the people to whom they are giving advice. For example, a scientist spoke at length about the ways in which he interacts with the various groups:

... the terms under which we interact are more or less defined by them ... can you come in and give us a talk? Can you come and present at this conference? Will you accept this subpoena to be an expert witness? ... each group I interact with in a very different way ... the modality of engagement could be quite different ... (Scientist B).

During the interviews, we asked the scientists what particular capacities or abilities they had needed to develop in order to engage with each group. This scientist's response is below:

[You need] the ability to put yourself in their shoes and understand it at the level that they interpret, like everyone doesn't have a complete story in their own mind and a complete set of tools to deal with the problems, so you need to keep understanding their scenarios and their circumstances and their risk perceptions and their priorities.

... It's a personal inter-relationship with people, and an ability to develop a trusted engagement and a friendship. They're all the same reasons why you'd interact with a friend or have an ongoing relationship with a group of people you socialise with. There's almost no difference between the two, and I find it very challenging to deliver a project with somebody that you can't develop that relationship with, because without trust and confidence, nothing really moves forward smoothly (Scientist B).

Another scientist recognised that scientific recommendations might have consequences broader than the science:

... that to me has been the thing that scientists, a lot of scientists particularly in my field, don't tend to recognise. They've very good at saying - these are the things that should be done, but they don't look at the consequences [for people] of doing those things (Scientist C).

For this scientist, to advocate for a particular point of view was to risk compromising trust in his science. Rather, he saw himself as presenting the evidence that underpinned his recommendations and thereby gaining trust:

I've had some really interesting discussions with farmers after talks and things like that, because their response has always been-we don't like what you're saying, but we can actually see what you're saying is right, rather than advocating things which then, to me, sets you at a... almost into a conflict ... (Scientist C). 
For a scientist whose work involves dealing with natural disaster, such as drought, flood or fire, that work can be difficult and emotionally taxing. One such scientist spoke of the willingness of the public "to try and make something good of what's happened" and to "tell their story to people that may be able to aggregate it and teach others" (pseudonym withheld for anonymity).

\section{The extent to which the scientists saw their school education as preparing them for their interactions with the public}

We asked the scientists a series of questions about the ways in which their school education might have prepared them to work with other people as they did. Most remembered learning science content, and a few told us that school had taught them something about how science works. In a scientists' words:

What did school science teach me? School science taught me that you look for evidence. School science taught me that you have to weigh up evidence that you apply arithmetic or mathematics to looking at the problem and to deducing robust results from whatever it is you're studying (Scientist D).

However, school science had not equipped the majority of these scientists for the interactions with their communities:

Interviewer: If you go back and think about your school science education, did it do anything at all to help you in your work as a scientist in dealing with all of these groups you've identified?

Scientist D: No

Interviewer: Okay. Did it contribute in any way to your capacity to engage as a scientist in conversation with the public?

Scientist D: No

Interviewer: So did the sort of school science that you did equip, do you think, the average non-specialist member of the public to engage in a conversation with science and scientists?

Scientist D: So the other kids in my school?

Interviewer: Yeah

Scientist D: No

Some scientists in our study saw school science's silence about the ways in which science as society interacts as unproblematic. Others saw this gap as a significant omission. In response to the question "Did [school science] teach you anything about the social responsibility of scientists and the institutions of science?" one scientist answered:

No, no. And I would say ... I mean it's there underneath, but I don't think it's articulated very much at all even through uni. ... We all know that there are certain protocols, and those would be taught of course ... or safety in the chem. lab ... you know those kinds of ethical considerations and responsibility, but the really large questions [laugh] ... frankly are just not discussed, and I think it does a big disservice both to the public and to students that are pursuing science, because it leaves them without even knowing... if they should come across something that is causing them to feel some conflict, they don't even know where to turn ... there's conflict of interest questions in terms of where you get your funding... There could be questions, I mean okay, climate scientists - do they have an obligation to speak through the media if 
they think... based on what they currently know, that you know certain very important things might be under threat? Medical research — at what point do you communicate something... actively communicate something to the public? That's actually an important question because... as you know, often scientific results, one by one by one are pretty small, and they have a lot of caveats around them, but the ones that get out into the media, they're usually oversimplified ...

... and this causes great conflicts for scientists. So... and at what point... you know there are responsibilities to your discipline, which I think you are taught it, even if indirectly, you know, and lawyers would feel that, and doctors would feel like you sort of understand what your responsibilities to your discipline is- to be a good doctor, to be a good scientist, but this interaction with the public I think is much more complex and not openly discussed. (Scientist E)

\section{Post-patrimonial governance and science education}

\section{A shift from patrimonial to post-patrimonial governance?}

Patrimonial governance is characterised by command relationships, in which experts are awarded authority over the laity in exchange for the protection they provide. In science, this authority may include the right of input into policy in a variety of societal areas in which science is deemed to be relevant, or the authority to make decisions on behalf of individuals or communities who do not have specialist expertise. The authority may be benevolent in its intent; nonetheless, it has a key limitation, namely that the protection is awarded in exchange for obedience and the relinquishment of agency.

Broadly speaking, post-patrimonial governance is characterised by a shift away from patrimonial command relationships; however, it may be characterised by new command relationships in which non-specialists are, effectively, expected to take responsibility for deciding matters that are beyond their grasp and this is the relationship of neopatrimonial governance that characterises neoliberalism. By contrast, the post-patrimonial governance consistent with relational contractualism seeks to provide support without command: this is support that strengthens the capacity of all parties to discuss and negotiate matters that are difficult, sensitive and emotionally charged. By this support the laity becomes better aware of the potential of specialist knowledge and is supported to make choices based on this knowledge. In what follows, I will refer to this as relational post-patrimonialism.

This study provides evidence that some Australian scientists are working in ways that are consistent with relational post-patrimonial governance, at least in some of their interactions with the laity. It is possible that some of the scientists in this study, perhaps most of them, including some of those who chose to work collaboratively with the public, were and are motivated by patrimonial considerations of public service and duty; nevertheless, they spoke of trying to work in ways more consistent with relationships of reciprocal respect than with patrimonial command relationship. Specifically, these scientists spoke of developing relationships of trust, of trying to see things from a variety of points of view and of being open to providing information while leaving decisions in the hands of the laity. To some extent the scientists are doing this because their science requires that they interact with a sector of the public and these are the terms expected by that public, but this is not their only motivation. Some scientists choose to work with their communities in ways that 
are responsive to community needs and on the community's terms because this way of working gives them satisfaction, and some are motivated by a vision of a good society.

\section{Science education that equips future scientists for post-patrimonial governance}

Contemporary scientists work in a variety of ways and only a few of these are acknowledged in science education policy and curriculum. The existence of this variety means that policy developers and curriculum writers can choose particular accounts of science to give in schools, both in terms of the range of accounts they give and also in the choice of which ways of working are prioritised and which ways of working are silenced. By these choices they shape the expectations of children, their parents and their communities as to what science is and what scientists do and ought to do: effectively they shape the ongoing relationships between scientists and their societies. They also by implication convey a sense of what counts as a good society, of what might constitute appropriate activity on the part of a scientist and on the part of the citizen laity. Thus, at the heart of debates about science education policy lie a number of beliefs about citizens and their relationships with expertise. Beliefs of this sort are implicitly invoked in discussions about the importance of scientific knowledge for citizens (Feinstein 2015). I invoke them here in a discussion about the education of future scientific specialists.

Most of the scientists in this study could not be said to have had a contemporary school education. Their science education is likely to have been strongly shaped by the "Alphabet" curriculum reforms of the 1960s that were highly influential in shaping the science curricula in Australian schools at the time (Fensham 2015) and have been "astonishingly robust in seeing off the alternatives" (Fensham 2016, p. 165). Thus, it is likely that that their education will have implicitly prepared them for a society in which experts were in patrimonial command relationships with the laity. Unsurprisingly, then, most of the scientists, including some of the more recent graduates, recalled their school science education as doing little to prepare them for their contemporary conversations with non-scientists. However, it is clear that some aspect of their education, formal or informal, in school or out of it, equipped them to try to interact with others in relationships of trust, care and sympathy — or at the very least did not persuade them that such relationships were unwise or unnecessary or impossible or otherwise inappropriate to attempt. The development of these capacities is consistent with an education for patrimonial governance, where the expert is awarded authority but also has a duty of care and the public is awarded protection in exchange for showing respect and obedience. This is a fragile obligation, because it relies on the expert seeing the laity as worthy of protection: nonetheless, the possibility exists. However, this view of relationships between experts and the laity is diametrically opposed to the interaction between a buyer and seller, where it is the buyer who is made responsible to exercise caution and the seller is exempted from showing care except to the extent necessary to comply with regulation and avoid future difficulty.

Hence, an education that supposes neopatrimonial command interactions between scientists and the public is likely to provide a poorer preparation for intelligent interactions of reciprocal respect than the patrimonial visions of the past. Both of these would teach a future scientist that his or her duty is to the disciplinary well-being of science, framed narrowly as canonical science, but neopatrimonialism exempts the scientist from any further responsibility except to commercialise their knowledge. At the same time, the patrimonial visions of the post-war welfare state form a poor basis for contemporary neoliberal governance because they cannot equip scientists to interact 
with contemporary publics, who may be disinclined to show respect and obedience, and who may treat experts with the mistrust appropriate to the market even where that expert intends a very different relationship. This has been referred to as a trust deficit on the part of the public (Bauer, Allum and Miller 2007). Put bluntly, our future scientists need different and better nuanced accounts of science and society than the accounts that served their predecessors (see, for example, Mikulak 2011 for a discussion on communication between scientists and the laity about MMR vaccination).

Writing of a school science curriculum, Douglas Roberts (2011) described the landscape of science education as characterised by competition between two competing visions for the purposes of learning science. Vision 1 looked inwards to the discipline of science itself and tended to treat school science as if its primary purpose was to develop a potential scientist pool (see also Roberts 2007). By contrast, Vision 2 looks to situations where science plays a role in human affairs and sees the purpose of school science as having students develop the capacity to handle science-related situations they might encounter in their adult lives. Roberts stressed that these visions provided pointers and general orientations rather than definitions, yet he describes these two visions as having been "in competition for a very long time" (Roberts 2011, p. 12). A post-patrimonial perspective allows us to resolve this competition, at least in schools. As this study shows it is possible to look inwards to science and see science that plays a part in human affairs; hence, if Vision 1 is restricted to looking inwards to canonical disciplinary science, that restriction will serve future scientists poorly. If, on the other hand, Vision 1 is allowed to enlarge to encompass scientists such as those in this study, then it will, at times, look very much like Vision 2. Future scientists will see that it is necessary for science that they try to value the perspectives of the laity and to understand that priorities set from a lay perspective can have real impact on the development of science knowledge. This enlargement of Vision 1 science would, amongst other things, consider questions about how science is funded; when and how scientists should interact with the media; and the complexity of the processes involved in bringing to society an advance in medical technology. It would ask difficult questions about responsibility to science and responsibility to the community and not seek to provide simple answers to all of these. These approaches must be included as part of a science curriculum so that it is clear that they form part of the legitimate concerns of science and thus are legitimate considerations in the work of scientists.

What I am recommending here is that all students-future scientists and future laity alike-should be equipped for intelligent interactions of reciprocal respect through a school education that has in the past been seen as more appropriate for the laity than for future specialists, namely a study of science in its social and political context. This approach is consistent with the priorities of many movements in science education, from the Science-Technology-Society (STS) movement (Aikenhead 2003) to the more recent interest in teaching science from socio-scientific issues (SSI) (Levinson 2012) or through asking and answering socially acute questions (SAQ) (Simonneaux 2014). Certainly, future scientists also will have to learn a good deal of canonical science: opportunities to do that exist in the STS, SSI and SAQ approaches and perhaps some of that knowledge might be left for their post-school education, or gradually introduced in the post-compulsory years of schooling. What will be different is the account that these future scientists are given in school of the possible ways in which scientists might work with other citizens. 


\section{A science education that equips future citizens for post-patrimonial governance}

Not all students take science at university but most students study science in school; if there is some science knowledge or knowledge about science that we want all future citizens to have a chance to learn, then it should be taught in schools. One such understanding is that scientists and other citizens interact in a variety of ways. Relationships of reciprocal respect require reciprocity, and it is important that both scientists and the laity are equipped to recognise invitations to engage in intelligent interactions about science.

Evidence from the literatures of science education suggests that some scientists are working in ways consistent with the neopatrimonial command relationships of neoliberalism (see, for example, Carter 2017). This study provides a counterexample to show that some Australian scientists are working in ways that are consistent with relational post-patrimonial governance, at least in some of their interactions with the laity. Thus, alongside the accounts of science and the work of scientists that highlight individualised entrepreneurship and market success, students also could be shown the possibility of relational post-patrimonial relationships and teachers could be thus be provided with opportunities and invitations to teach against the grain of neoliberalism. To be clear, I am not recommending that this language be used in schools, but rather that students be offered opportunities to learn about situations where scientists worked alongside other citizens to produce knowledge pertinent to their immediate context and of benefit to individuals and the community. In Australia, these contexts could include those in which the scientists in this study worked. Studying these contexts might allow students to meet practicing scientists who work with their own communities. In learning about the work of scientists like these, all students also would be offered the chance to learn a good deal of canonical science.

However, not all students should be expected to necessarily master all aspects of the canon. The rhetoric of science education for participatory democracy can be read as a demand that the professional scientist and laity become equal in terms of expertise. Why else should we try to teach so much "valid science" to students who will rarely, if ever, in their future lives need to understand this science in this form? In a move that is uncomfortably close to Bauman's (2013) description quoted above, students are being prepared to be made responsible for matters that will inevitably elude their future grasp. In addition to the canonical science content, the responsible citizen is being asked to understand the interaction of science with society, to think of science as a human enterprise that may be as flawed as the humans who engage in it, to appreciate that scientific truth is not absolute (in the terms of constructivists, socially constructed) but that the findings of science have validity yet. There is a real risk that, implicitly, the future laity is being prepared to be positioned as constantly deficit in their understanding of science (see, for example, Metcalfe 2019 for a discussion of science communication practices in Australia).

Relational post-patrimonialism recognises that there is a limit to the canonical science content understanding that can be asked of the laity. Rather, this perspective recognises that "we should expect a fundamental difference in the knowledge of a scientist and a layperson" (Mikulak 2011, p. 207), and that science education for all citizens should equip them to "recognize the moments when science has some bearing on their needs and interests and to interact with sources of scientific expertise in ways that help them achieve their own goals" (Feinstein 2011, p. 13). This applies also to the occasions when scientists interact with science that is outside their field, when it is important that they understand that sometimes they, also, are outsiders. Preparation for intelligent interaction should include teaching that sometimes when it comes to science, common sense does not constitute good 
sense and there are times when experts are better placed to decide the best course of action than the laity. There is an important corollary to this understanding, namely that citizens should understand that there is a limit to the extent to which expert knowledge can be represented in everyday terms. This recognition places the responsibilities of the citizen scientific laity in a different light, because rather than expecting each person as an individual to handle the technical scientific aspects of a socio-scientific issue, we expect them to be open to working collaboratively with people whose expertise is different from their own.

This perspective presents a significant challenge to school education as we know it today because it challenges a view that knowledge, and consequently learning, is individualised. The view calls into question the ways in which assessment is structured as measuring individual achievement rather than a contribution to a collective outcome. It asks that teachers and curriculum developers think across highly disciplined school structures and recognise that, for example, scientists, geographers, political scientists, engineers and journalists all have relevant perspectives on climate change (Hulme 2010). It also draws attention to the many occasions on which individual choices have collective consequences and conversely, where individual choice has no purchase in the face of collective actions. This is true for climate change where the actions of individuals can only go so far when faced with "the clumsiness of climate governance" (Hulme 2010, p. 309); it is an insight that also can be taught through the study of any number of other socially acute problems including vaccination (Fensham 2014), antibiotic resistance in bacteria (D. V. Smith 2011), the control of species perceived as pests (France, Birdsall and Simonneaux 2017) and, in Australia, by studying local uses of water and soil conservation in their scientific, technological, political and social contexts. To give another immediate example, the responses of different countries to the emergence of Covid-19 have vividly illustrated that real-life problems have multiple dimensions. Although science may give us single correct answers about the structure of the virus, how it is transmitted and how it should be treated, there are likely to be a variety of appropriate approaches to how this knowledge is enacted as policy and practice. Clearly, there are some approaches that are better than others, but it is unlikely that a single best approach will apply in all situations. It also shows that the choices of individuals matter to a community; in this situation, people's very lives depend on the choices of others.

\section{Conclusion}

Professional scientists, in order to do their work, must acquire knowledge that is narrow and esoteric and it is clear from our study that the scientists valued their training in canonical science. However, this must not be the only knowledge they gain. The education in a secondary school science classroom of both future scientists and future non-scientists must adopt a view of science that is more than narrowly cognitive, must acknowledge that science can encourage a perspective that is narrow and esoteric but must ground this narrow view against a wider context. A science education for all citizens should equip them for intelligent interactions with scientists. A school science education for future scientists should support them to deal with their responsibilities to their discipline, and it should also acknowledge and prepare them for their interactions with the public, a much more complex area that is not, at present, widely discussed.

A school science curriculum, explicitly and by implication, conveys a sense of what counts as a good society, and of what might constitute appropriate activity on the part of a scientist and on the part of the citizen laity. Education policy and practice govern into 
existence society's future and contemporary education policy tends to govern into existence neoliberal subjects and subjectivities that entrench neopatrimonial command relationships as the norm. Societies such as Australia are facing a significant challenge to our capacity to see that there is no individual without community. In science education this challenge is manifested by a strongly vocational approach to the education of intending science specialists, while the science education of future laypeople is focussed on teaching them a good deal of the scientist's science in order that they be able to participate in a scientific society. Effectively, this approach means that both future scientist and future layperson encounter, in secondary school, a science curriculum that neither acknowledges the social nature of science nor challenges the dominant rhetoric of individualism.

The existence of scientists who are trying to work with their communities in relational post-patrimonial ways means that as science educators and science curriculum developers we have choices about how we portray the relationships between scientists and society. Our agenda as science educators could be that we acknowledge the vision of relationships of reciprocal respect between scientists and their communities provided by many of the scientists in this study and educate future scientists and future citizens in ways that recognise, value and support such relationships.

Acknowledgements This research was funded by the Australian Research Council, Discovery Grant DP120102714. The research team was Dorothy V. Smith, Pamela J. Mulhall, Richard F. Gunstone and Christina E. Hart and the research was done at La Trobe University and Monash University. The version of this article first submitted for review was written while the author was on study leave in Manchester UK, as an Honorary Research Fellow within the Faculty of Humanities at The University of Manchester working within the Critical Education Policy research group. She acknowledges financial support from La Trobe University and the award of honorary status from The University of Manchester. The author would like to thank the reviewers and lead editor for their comments and constructive criticism.

\section{References}

Aikenhead, G. S. (2003). STS education: a rose by any other name. In R. T. Cross (Ed.), A vision for science education (pp. 59-75). London and New York: Routledge Falmer.

Ball, S. J. (2008). New philanthropy, new networks and new governance in education. Political Studies, 56(4), 747-765. https://doi.org/10.1111/j.1467-9248.2008.00722.x.

Bauer, M. W., Allum, N., \& Miller, S. (2007). What can we learn from 25 years of PUS survey research? Liberating and expanding the agenda. Public Understanding of Science, 16(1), 79-95. https://doi. org/10.1177/0963662506071287.

Bauman, Z. (2013). The individualized society. Oxford, UK: Polity Press.

Beck, U. (1997). The reinvention of politics : rethinking modernity in the global social order. Cambridge, UK: Polity Press.

Beck, U. (2000). Risk society revisited: theory, politics and research programmes. In B. Adam, U. Beck, \& J. Van Loon (Eds.), The risk society and beyond: critical issues for social theory (pp. 208-238). London, UK: SAGE Publications.

Carney, T., \& Ramia, G. (2001). Contractualism and citizenship: rivals or bedfellows? Law in Context, $18(2), 8-33$.

Carney, T., Ramia, G., \& Yeatman, A. (2001). Contractualism and citizenship. Law in Context, 18(2), 1-7.

Carter, L. (2017). Neoliberalism and STEM education: some Australian policy discourse. Canadian Journal of Science, Mathematics and Technology Education, 17(4), 247-257. https://doi.org/10.1080/14926 156.2017.1380868.

Carter, L. (2018). STEM education as a GERM. In Z. Joseph (Ed.), Globalisation and education reforms: paradigms and ideologies. Dordrecht: Springer.

Carter, L., Weinstein, M., \& Bencze, L. (2017). Biopolitics and science education. Cultural Studies of Science Education, 12(4), 761-767. https://doi.org/10.1007/s11422-017-9845-x.

Feinstein, N. W. (2011). Salvaging scientific literacy. Science Education, 95(1), 168-185. https://doi. org/10.1002/sce.20414. 
Feinstein, N. W. (2015). Education, communication, and science in the public sphere. Journal of Research in Science Teaching, 52(2), 145-163. https://doi.org/10.1002/tea.21192.

Fensham, P. J. (1985). Science for all: a reflective essay. Journal of Curriculum Studies, 10, 346-356. https://doi.org/10.1080/0022027850170407.

Fensham, P. J. (2014). Scepticism and trust: two counterpoint essentials in science education for complex socio-scientific issues. Cultural Studies of Science Education, 9(3), 649-661. https://doi. org/10.1007/s11422-013-9560-1.

Fensham, P. J. (2015). Curriculum movements in science education. In R. Gunstone (Ed.), Encyclopedia of science education (pp. 275-279). Dordrecht: Springer, Netherlands.

Fensham, P. J. (2016). The future curriculum for school science: what can be learnt from the past? Research in Science Education, 46(2), 165-185. https://doi.org/10.1007/s11165-015-9511-9.

France, B., Birdsall, S., \& Simonneaux, L. (2017). Analysing the multiplicity of voices in the agora: using actor-network theory to unravel a complex issue. International Journal of science Education, Part B, 7(4), 323-340. https://doi.org/10.1080/21548455.2017.1342285.

Gilbert, J. (2013). What kind of thing is 'neoliberalism'. New Formations, 80-81, 7-22. https://doi. org/10.3898/NEWF.80/81.INTRODUCTION.2013.

Gough, A. (2015). STEM policy and science education: scientistic curriculum and sociopolitical silences. Cultural Studies of Science Education, 10(2), 445-458. https://doi.org/10.1007/s1142 2-014-9590-3.

Harvey, D. (2007). A brief history of neoliberalism. Oxford, New York: Oxford University Press.

Hayek, F. A. (1978). New studies in philosophy, politics, economics and the history of ideas. London and Henley: Routledge and Kegan Paul.

Hoeg, D., \& Bencze, L. (2017). Rising against a gathering storm: a biopolitical analysis of citizenship in STEM policy. Cultural Studies of Science Education, 12(4), 843-861. https://doi.org/10.1007/ s11422-017-9838-9.

Hulme, M. (2010). Why we disagree about climate change. Cambridge, UK, New York: Cambridge University Press.

Jasanoff, S. (Ed.). (2013). States of knowledge: the co-production of science and the social order. Hoboken: Taylor and Francis.

Layton, D., Jenkins, E., Macgill, S., \& Davey, A. (1993). Inarticulate science? Perspectives on the public understanding of science and some implications for science education. Nafferton, Driffield: Studies in Education Ltd.

Levinson, R. (2012). Practice and theory of socio-scientific issues: an authentic model? Studies in Science Education, 49(1), 99-116. https://doi.org/10.1080/03057267.2012.746819.

Malcolm, C. K. (2003). Science for all: learner-centred science. In R. T. Cross (Ed.), A vision for science education. Routledge Falmer: London and New York.

Marginson, S. (1997). Educating Australia: government, economy and citizen since 1960. Cambridge, Melbourne: Cambridge University Press.

Metcalfe, J. (2019). Comparing science communication theory with practice: an assessment and critique using Australian data. Public Understanding of Science, 28(4), 382-400. https://doi. org/10.1177/0963662518821022.

Mikulak, A. (2011). Mismatches between 'Scientific' and 'Non-Scientific' ways of knowing and their contributions to public understanding of science. Integrative Psychological and Behavioral Science, 45(2), 201-215. https://doi.org/10.1007/s12124-011-9157-8.

Mills, C. W. (1997). The racial contract. Ithaca: Cornell University Press.

Mulhall, P. J., Smith, D. V., Hart, C. E., \& Gunstone, R. F. (2017). Contemporary scientists discuss the need for openness and open-mindedness in science and society. Research in Science Education, 47(5), 1151-1168. https://doi.org/10.1007/s11165-016-9554-6.

Palmer, S., Campbell, M., Johnson, E., \& West, J. (2018). Occupational outcomes for Bachelor of Science graduates in Australia and implications for undergraduate science curricula. Research in Science Education, 48(5), 989-1006. https://doi.org/10.1007/s11165-016-9595-x.

Pateman, C. (1988). The sexual contract. Cambridge, UK: Polity Press.

Roberts, D. A. (2007). Scientific literacy/science literacy. In S. K. Abell \& N. G. Lederman (Eds.), Handbook of research on science education (pp. 729-780). New York, London: Routledge, Taylor and Francis Group.

Roberts, D. A. (2011). Competing visions of scientific literacy: the influence of a science curriculum policy image. In C. Linder, L. Östman, D. Roberts, P.-O. Wickman, G. Erickson, \& A. MacKinnon (Eds.), Exploring the landscape of scientific literacy (pp. 11-27). New York: Routledge.

Saul, J. R. (1997). The unconscious civilization. Ringwood: Penguin Books Australia. 
Simonneaux, L. (2014). Questions socialement vives and socio-scientific issues: new trends of research to meet the training needs of postmodern society. Topics and trends in current science education (pp. 37-54). Dordrecht: Springer.

Smith, D. V. (2007). Scientists are also citizens: science curriculum from the perspective of the new contractualism. Melbourne: Monash University.

Smith, D. V. (2011). Becoming a scientist means becoming a citizen. In C. Bruguiere, A. Tiberghien, \& P. Clement (Eds.), The ESERA 2011 conference (Vol. 9, pp. 69-75). Retrieved 27 May, 2020, from http:// lsg.ucy.ac.cy/esera/e_book/base/index.html

Smith, D. V., \& Mulhall, P. J. (2015, 25 November). Getting it on the table: using diagrams and graphs within an Interview. Paper presented at the 2015 Contemporary Approaches to Research Symposium, Deakin University Melbourne City Centre.

Smith, D. V., Mulhall, P. J., Gunstone, R. F., \& Hart, C. E. (2015). What account of science shall we give? A case study of scientists teaching first-year university subjects. International Journal of Science Education, 37(9), 1504-1523. https://doi.org/10.1080/09500693.2015.1042942.

Smith, D. V., Mulhall, P. J., Hart, C. E., \& Gunstone, R. F. (2016). Contemporary high-profile scientists and their interactions with the community. International Journal of Science Education, 38(10), 16071621. https://doi.org/10.1080/09500693.2016.1201236.

Smith, D. V., Mulhall, P. J., Hart, C. E., \& Gunstone, R. F. (2018). Contemporary scientists and their interactions with non-scientists: alternative companion stories for school curricula. Research in Science Education. https://doi.org/10.1007/s11165-018-9765-0.

Smith, J. A., \& Osborn, M. (2008). Interpretative phenomenological analysis. In J. A. Smith (Ed.), Qualitative psychology: a practical guide to research methods. London: Sage.

Weinstein, M. (2016). Critiquing and transcending STEM. Journal for Activist Science and Technology Education, 7(1). Retrieved 26 March, 2020, from https://jps.library.utoronto.ca/index.php/jaste/article/ view/26828

Yeatman, A. (1997). Contract, status and personhood. In G. Davis, B. Sullivan, \& A. Yeatman (Eds.), The new contractualism? (pp. 39-56). South Melbourne: Macmillan Education Australia.

Yeatman, A. (2000). The politics of postpatrimonial governance. In T. Seddon \& L. Angus (Eds.), Beyond nostalgia: reshaping Australian education (pp. 170-185). Melbourne: The Australian Council for Educational Research.

Yeatman, A. (2002). The new contractualism and individualized personhood. Journal of Sociology, 38(1), 69-73. https://doi.org/10.1177/144078302128756480.

Yeatman, A., \& Owler, K. (2001). The role of contract in the democratisation of service delivery. Law in Context, 18(2), 34-56.

Publisher's Note Springer Nature remains neutral with regard to jurisdictional claims in published maps and institutional affiliations.

Dorothy V. Smith is interested in the ways in which neoliberalism is impacting on individuals and society, and in particular its impacts on relationships between experts and the laity. She uses this lens to consider interactions between contemporary scientists and their publics and the ways in which disciplinary knowledge is transfigured in and by the turbulent contexts of its use. She is, as a consequence, committed to developing science curriculum in schools and universities that reflects the diversity of contemporary science. At the time of writing this article, Dorothy was a Senior Lecturer in the School of Education at La Trobe University in Melbourne, Australia, and Honorary Research Fellow within the Faculty of Humanities at The University of Manchester, UK. She is now Associate Professor and Head of Department, STEM Education in the School of Education at the University of New England, Armidale, Australia. 